\title{
The Material Culture of Chilean Exile: A Transnational Dialogue
}

\author{
JoAn Simalchik
}

\begin{abstract}
In the aftermath of the 1973 coup d'état, Chileans managed to find refuge in more than forty of the world's countries. They left with the expectation that they would only need temporary asylum, but instead found themselves in a state of prolonged exile. In order to speed the day of return and as antidote to the trauma of exile, Chileans created communities in opposition to the Pinochet dictatorship. Through resistance strategies enacted in a constructed site of struggle, Chilean exile communities facilitated remembrance through commemorative practices, cultural forms, testimony, and the preservation of endangered material culture that became decisive for legal cases against impunity and as a basis for historical inquiry.
\end{abstract}

\section{Resumé}

À la suite du coup d'État de 1973, les Chiliens ont réussi à trouver refuge dans plus de 40 pays dans le monde. Partis en croyant n'avoir besoin que d'un asile temporaire, ils se sont plutôt trouvés en exil prolongé. Les Chiliens ont mis sur pied des groupes opposés à la dictature de Pinochet afin de raccourcir l'échéance de leur retour et comme antidote au traumatisme de l'exil. Grâce à des stratégies de résistance déployées dans le lieu présumé $d u$ conflit, les communautés chiliennes en exil ont perpétué le souvenir par des pratiques commémoratives s'appuyant sur des formes culturelles, des témoignages et la préservation du matériau culturel menacé. Ces pratiques sont devenues décisives en matière de défense juridique contre l'impunité tout en servant de base à la recherche historique. significant repercussion of the 1973 coup d'état, and
the ensuing Pinochet dictatorship, was the need for
Chileans to find asylum outside of their country. From the beginning of its rule, the junta issued proclamations pronouncing its intent to rid Chile of "the cancerous tumor" of members and supporters of the Popular Unity government. ${ }^{1}$ The rhetoric was backed up with deed as the military institutionalized persecution of its opponents. Chilean refugees would soon find themselves to be an incipient part of an emerging transnational diaspora.

In its initial plan to recreate Chile based along the lines of its own ideology, the junta sought to people the country only with those who shared its objectives or, at least, with those who would not challenge them. In order to fulfill this aim, the junta decreed outright that selected Chileans would be forbidden to live in their own country. Those who were designated to be enemies of the newly evolving regime, or perceived to be so, were to be excised from the body politic. In its efforts to rid Chile of potential opposition, the military junta began to define who would be permitted to remain in the country. At the start, the category of personae non grata included leaders and members of the Popular Unity Coalition, leaders and members of socially active organizations linked to the left including trade unions, student federations, and women's groups and others deemed likely to challenge the authority of the military junta. Beyond the repressive practices that sought to marginalize opposition through termination of life, freedom, or employment, the military went further by terminating the right to live in Chile.

For those who found themselves under the gun, the distance from past to present was difficult to negotiate, especially because of the rapidity of the turnaround. Ariel Dorfman provided a flavour of this predicament in a section of his memoir entitled "A Chapter Dealing with the Discovery of Death inside an Embassy in October of 1973, in Santiago de Chile." Dorfman remembered his time in- 
side the Argentine Embassy as one of nine hundred wouldbe refugees where he meets

. . . face-to-face, the first torture victims of my life . . laid out side by side in the great ballroom of the embassy, where only a month ago tuxedoed men leaned forward to murmur compliments to women in long, shuffling dresses, where one of the fugitives himself, Allende's Secretary of the Treasury, sipped a cocktail next to the very piano under which he now tosses and turns, trying to get some rest. ${ }^{2}$

As a consequence of the repression, hundreds of thousands of Chileans from the 1973 total population of ten million came to be living in the "remote havens of foreign lands." ${ }^{3}$ Decree Law 81 promulgated in November 1973 and Supreme Decree 604 in June 1974 set out the rationale for stripping citizenship and refusing the right to live in Chile. The military regime drew up a National List (Lista Nacional), which included approximately five thousand names of Chileans deemed to be undesirable. An " $L$ " indicating a name on the List was stamped on the passport and forbid entry into Chile. The List was modified during the seventeen years of the dictatorship but it was only abolished in 1989 as part of the transition to democracy negotiations. While not all Chileans who fled the regime were formally put on the List, its existence posed a constant threat to exiles who publicly opposed the regime.

Some Chileans began life in exile after enduring long, tedious, and bureaucratic immigration processes such as the one begrudgingly undertaken by Canada. ${ }^{4}$ Some languished for months in limbo-like conditions in foreign embassies in Santiago or in interim countries such as Panama while they awaited resettlement. Many Chileans were not able to choose the country to which they were going, and had no time to prepare or plan for the journey.

The problem Estela de Ramirez had when she arrived in Canada was that she had nothing to hold on to. At most some pictures in an issue of National Geographic from who-knowswhen... when Estela de Ramirez was told that tomorrow she was going to Canada, nothing came to her mind. Canada. ${ }^{5}$

In the aftermath of the coup d'état, Chileans managed to find asylum in more than forty countries throughout the thendivided first, second, and third worlds. ${ }^{6}$

This group of exiles left Chile with the expectation that they would only have need of a temporary safe haven. Their commonly held belief predicted that exile would be short because the military regime was expected to collapse under the combined weight of Chile's democratic history and civilian political tradition. These were not immigrants seek- ing a new land, nor were they refugees hoping to be permanently resettled. This group of Chileans, who self-defined as exiles, intended to return to their country to continue their thwarted political project as soon as it was possible to do so.

As testament to the notion of inevitable return, El Retorno, deposed President Salvador Allende was frequently invoked. In his last radio address, broadcast shortly before his death on the day of the coup, Allende appealed: "... to keep the faith. Neither criminality nor repression can hold back history." He anticipated: "May you continue to know that sooner rather than later the great avenues through which free men walk to build a better society will open."7 These words found themselves inscribed on banners and pamphlets, and became a watchword in the early days of the Chilean exile. "The hope of return helped us not to be separated emotionally from our history with Chile."8

In order to speed the day of return, Chilean exiles reconstituted themselves as the political expression of those silenced in Chile. Chile's pre-existing political, ideological, and social divisions now included a geographical dimension. Chileans were separated from each other spatially and were designated according to their location "inside" or "outside" of the country. In truth, the exiles inhabited "... a space that in territorial terms does not coincide with one particular country but falls in between two or more countries." Along with the geographical divide of the exile condition, there exists a temporal disruption: “. . the exile lives in two different times simultaneously, in the present and in the past."10 The tension of maintaining a balance between shifting coordinates of time, place, and memory serves as a particularly demanding burden of exile.

This group was distinct from many of the previous exile movements in both number and type although the experience of forced migration in the twentieth century was not unique to Chileans. The Garden of Exile in Berlin's Jewish Museum designed by Daniel Libeskind conveys an expression of the experience of German Jews before and during World War II. The museum's tour begins in the basement Hall of Decision with the visitor forced to choose between continuing on the tour upstairs or entering the Garden of Exile, a concrete maze with slanted floors. ${ }^{11}$

The Chileans, though, like the Spanish Civil War refugees before them, bridged the shift from E. H. Carr's notion of the few select political leaders, The Romantic Exiles, ${ }^{12}$ to those masses composing the new movement of asylum seekers termed the "age of refuge" by Edward Said. ${ }^{13}$ The Chileans would be distinguished by their intent to return to their homeland and presaged the large-scale refugee movements that would characterize much of the latter part of the century. In 1973, many countries in which Chileans 
sought asylum were ill-prepared to meet the challenge. For those countries that had signed the United Nations Convention on Refugee Status, most had not established the necessary framework in order to execute a process for refugee determination. ${ }^{14}$ In many cases, Chileans found themselves to be the bridgehead for the development of refugee policy and (re) settlement services.

While the process of migration has been established to be a difficult and stressful time for anyone, forced displacement poses additional problems for people who become refugees. ${ }^{15}$ The multiple series of losses involved with the state of exile compounds the difficulty of refugee settlement. Loss of community, language, and culture and separation from family, friends, and comrades all put into sharp relief the gap between home country and host society.

The grieving process common to all uprooted groups is characterized in exiles or refugees by ambivalence towards adapting to the new society, and by anger at having been forced to leave. Interwoven is the survivor's guilt: the feelings arising out of being relatively safe, but with the knowledge that your loved ones and your political partners continue to be in precarious situations. ${ }^{16}$

"Refugee-survivors live in a state of extreme uncertainty about the future. Uppermost, in their mind, are questions about if and when they might be able to return to their country. The survivor lives metaphorically, if not actually, with his or her bags packed, ready to return home the moment it is possible." 17 For the most part, Chileans had arrived in exile with little more than memories of their political project in their bags and these memories were among the first belongings to be laid open.

The transition from state power to state of exile traversed more than the distance measured across international borders. The fate of those inside and those outside Chile was shared in the dimension of marginalization that both experienced. Both groups had been violently expelled from the fabric of the Chilean body politic. Those remaining inside Chile continued to be subject to direct persecution. Those outside of the country began to discover the unremitting condition experienced as the pain of exile. ${ }^{18}$

Coordinates of memory can be diminished for exiles. The passage of time exacerbates the distance from patria while, simultaneously, exile life is not represented in the mainstream culture of the host country. One aspect affecting the psychosocial traumatic consequence of forced exile is that people ". . . are unable to see themselves and their circumstances reflected back to them, and, kept from these reflections, are handicapped . ..."19 Refugee Chileans sought to build support for the human rights struggle at home while attempting to maintain their own culture in countries of asylum. Chileans sought to recreate in exile what they had performed in Chile. The form and content of cultural and commemorative practices could be replicated but these were enacted in a foreign terrain and conducted within a different contextual quality.

As antidote to the prolonged experience of exile, Chileans created communities in opposition to the dictatorship that had precipitated their predicament.

Exile has long been a political instrument of punishment, but because of its reflective qualities, it can (and often is) used against the tyrant. The exile becomes the tyrant's Doppelganger. He will always be there; nothing is more implacable than absence. History, through the shifting of viewpoints, may be forgiving; the exile is relentless in his accusation because his memory never changes. ${ }^{20}$

Even though the Chilean coup d'état had created sympathy in many sectors of the world community that had supported the Popular Unity government, it was still difficult for Chileans to establish communities in exile. Despite the challenges and with their implacable and relentless memories, once in the countries of asylum, Chileans quickly regrouped and reorganized themselves along the lines of the political parties and organizations to which they belonged. The parties of the Popular Unity were grouped under a solidarity organization, Chile Democratico, with international headquarters in Rome and a hemispheric base for the Americas in Mexico. The Moviemento de Izquierda Revolutionario (MIR; the Movement of the Revolutionary Left) had formed the left opposition to Popular Unity and organized their own solidarity efforts independent of the Popular Unity group in countries of asylum. Chile Democratico held the dual aims of maintaining the political objectives and culture of the Popular Unity government while at the same time exposing the repression of the military regime. For MIR, the solidarity watchword was resistancia, and the letter $\mathrm{R}$ superimposed on the Chilean flag symbolically espoused this. For both groups, the basis of activities focused on events in Chile. As the military regime entrenched itself, in counterpoint, exiled Chileans prepared to organize for the duration. Rapid recognition of the military junta by foreign countries prevented the organizations from forming a de jure or de facto government in exile. ${ }^{21}$

Ethno-specific organizations were also created in order to maintain cultural attributes and to promote a more inclusive perspective. Soccer clubs were given the names of people and objects with significance for the community, such as Salvador Allende and copihue rojo, the national flower. An exile literary journal was entitled Araucaria after 
the sacred tree of the Mapuche people, Chile's most numerous indigenous people, who are renowned for their fierce resistance to conquest. Heritage language schools were organized often in conjunction with local school boards in order to preserve Spanish expression and culture. In Toronto, the Salvador Allende School was established with the support of the Board of Education. Dance troupes, musical groups, and choirs were organized in efforts to replicate the folkloric traditions of the homeland. Many of these were named in memory of Victor Jara and Pablo Neruda. All these efforts sought to preserve Chilenismos, connecting past cultural practice with the intention to maintain memory for the return. ${ }^{22}$

The exile community coalesced around solidarity activities that sometimes perplexed the larger host society and frustrated the refugees. In Canada, a woman in exile recalled the difficulties of galvanizing support. "Comadre, I still remember the names of all those towns we went to. In some places, the public didn't even know where Chile was, let alone what happened there ...."23 Still, efforts by nationals in asylum countries assisted exile efforts and networks of solidarity spanned the globe. In Canada, the Coordinating Committee for Solidarity with Democratic Chile had local affiliates based throughout the country and some of them outlived the life of the dictatorship.

Exile activity inside international organizations assisted in efforts to expose the continuing repression inside Chile. Refugee Chileans initiated fact-finding tours by Amnesty International, the American Association for the Advancement of Science, the Canadian Council of Churches, and other bodies to go to the country and collect information of the state of human rights under the junta. This data was reported, sent to the United Nations and foreign ministries, and formed part of the evidentiary record of the situation in Chile. Health professionals performed examinations on the regime's victims and produces epidemiological reports on the practice of torture. The torture treatment movement was established in response to the specific needs of Chilean exiles and informed by the underground activity of health professionals in Chile.

Academics, many of whom had been expelled from Chilean universities, documented and analyzed from outside the conditions on the inside. They set up in exile research on Chile's history, media, arts, political economy, and corporate investment in the areas that had been proscribed by the dictatorship.

Exiles played a large part in establishing human rights concerns within trade unions, student organizations, and other civic associations. Resolutions condemning the Pinochet dictatorship and enlisting support for the exile effort helped to assist host societies to become more aware of the conditions causing refugee flight. The Canadian Labour Congress, along with the National Union of Students, the National Action Committee on the Status of Women, and the National Union of Farmers, were prominent among those supporting a boycott of Chilean products in Canada.

Chilean exiles from all walks of life contributed to the diaspora production of culture and material evidence. Artists from theatre, music, art, and film developed representations of the plight of democratic Chile through reproductions of significant historic pieces or through new compositions. The World Conference of Solidarity with Chile held in Madrid in 1978 hosted a companion fair. This presented a veritable cornucopia of solidarity items including matchbooks, hand-painted handkerchiefs, posters, key rings, mirrors with Neruda's image, tee shirts, mugs, flags, and jewelry created by exile communities throughout the world.

Exile organizations set in motion series of activities, tareas de solidaridad (solidarity tasks), in coordinated efforts to denounce the military regime and limit its influence. A sense of urgency surrounded the work so that Allende's prediction of democratic return would be accomplished "sooner rather than later." 24 In these solidarity activities, distinctions were drawn between events that were intended to preserve the past and those that were instituted in response to the repression in Chile. Each demanded its own sense of immediacy. Specific anniversaries of dates identified as significant ones were commemorated with homenajes (homages). Celebrations of past victories were memorialized. And a rapid reaction network was established to be able to respond to new atrocities carried out by the junta.

Internationally, exiles organized marches and rallies in response to the continuing persecution inside the country. These events retained many of the features of their Chilean roots, but were enacted with much smaller numbers than the ones held in the past in Chile.

Events that conveyed a celebratory tone included the birthday of Chile's first president, Bernardo O'Higgins, the country's traditional election date, the inauguration date of the Popular Unity government, and the foundation of the Workers' Central Union of Chile (Central Unica de Trabajadores se Chile, or CUT). These actos held in exile performed the function of preserving democratic traditions that had been outlawed inside the country. More, they held the possibility of hope as examples of victories to be won again.

Chile's national day, September 18, was observed as fiesta complete with comida typica (typical food) and cueca (Chile's national dance) contests. Anniversaries of the founding dates of political parties and movements, now 
banned in Chile, were celebrated with gusto in exile with invited greetings, speeches, cultural activities, and birthday cakes. The Chilean bandera was raised at each event and Popular Unity's anthem, "Venceremos" ("We Will Be Victorious"), and that of the resistance, "El Pueblo Unida Jamas Sera Vencido" ("The People United Will Never Be Defeated") were sung. Penas were held with folkloric music at which wine and empanadas were served and these created an opportunity for the community to socialize and to display and enact their cultural traditions. They also provided a useful function as fundraising events.

The exiles claimed the historic symbols of state for their own. The Chilean flag was not to be relinquished to the military regime but was maintained in exile for the time when democracy would return. The flag was ascribed with a democratic meaning and was connected by exiles as a legitimizing expression of their cause. It held a prominent place at most events and was used symbolically on letterhead, logos, and posters. After a number of years, the exiles began to sing Chile's national anthem and, without ceremony, it replaced "Venceremos" at events. Pride in patrimony was claimed by the exiles-Nobel-Prize-winning poets Gabriela Mistral and Pablo Neruda, internationally acclaimed pianist Claudio Arrau, along with painters, writers, academics, and legendary nationals. This form of patriotism extended into a cultural and civic space that had been obliterated inside the country and preserved in conditions of exile.

Exiles continued to represent their opponents, the military junta and its supporters, the same way they had in the pre-coup era-as momios (mummies). The new regime was depicted as being anomalous to modernity and it was characterized as being a political regression to antiquity. The designation of "momio" assumed an anachronistic quality, one in which this particular group of Chileans was seen as anti-historic and, therefore, as somewhat unnatural and politically and temporally deviant. They were characterized by the exiles as usurpers who had derailed the country from its historic mission by means of violence and held power through institutionalization of persecution.

Long before there was $9 / 11$ there was once de septiembre. Commemorations of the date of the September 11 coup d'état held complex and multi-dimensional meanings for exiles. Viewed as an occasion for celebratory victory by the junta in Chile, September 11 was declared to be an official national holiday inside the country. In contrast, for exiles, this date signified defeat. September 11 observances were ascribed a prophetic meaning, though, in the sense that these events were transformed from representing failure into ones that told the "truth." Inside Chile, the dictatorship controlled information and its dissemination. In exile, however, Chileans were able to convey to the outside world what the junta had censored and to ascribe events with their own political framing.

As such, these events became opportunities to gather support for the cause. Events held to commemorate the coup's anniversary served as public statements in opposition to the military regime and commitments to eventual triumph. Additionally, they assisted the community members to keep faith and provided a forum in which they could rededicate themselves to victory. The actos offered an occasion for affected members of the exiled Chilean community to assemble, to communally mourn, and to implicitly forge mutual understanding of circumstance. They provided a forum in which exiles could demonstrate determination to resist and to receive encouragement.

Prominent political leaders delivered keynote addresses analyzing strategy and tactics. Entire families attended and children learned of the broader context to their parents' solidarity activities. Care was taken to ensure that members from the host society-potential supporters of the cause-would be invited and translation from Spanish provided. September 11 also provided an opportunity for members of the community to grieve and mourn those who had suffered under the military junta. The tradition of naming the fallen, after which the rejoinder of "presente" was called out, served to maintain memory and connect the past to present and future. The necessity of recalling and restating the names of the martyrs to the Popular Unity project was particularly compelling in exile because these same names had been expunged inside the country.

In exile, Chileans wove together strands of memory with new information gleaned, often surreptitiously, from inside. As the underground resistance established itself inside Chile, exiles were able to connect with it and to disseminate documentation of life under dictatorship. In this way, they could continue to serve the Chilean struggle from outside the country by becoming conduits for the fledgling internal opposition to the regime. Exiles established links in order to communicate and receive information and they created safe spaces that allowed material evidence to be preserved.

The ephemera of the Popular Unity period-photographs, posters, records, banners-were carefully preserved and often duplicated. In addition, Chilean exiles disseminated material produced by the resistance to the dictatorship. Arpilleras, handmade tapestries depicting vignettes of contemporary life under the dictatorship, were first made by women relatives of the disappeared, executed, and imprisoned. They were widely distributed in exile and through efforts of Chileans were exhibited in many art museums and galleries. 
Other representations of Pinochet's Chile found international audiences by means of the exile diaspora. Soon after the coup d'état, a copy of Patricio Guzman's documentary footage of the time leading up to the military coup and its aftermath was smuggled out of the country in a Swedish diplomatic pouch through the efforts of the filmmaker's uncle. ${ }^{25}$ Guzman himself came to Spain as a refugee after his detention in the National Stadium and, in exile, he crafted a three-part documentary, The Battle of Chile. The film depicted the internal strife and debate during the Popular Unity government and portrayed the opinions of rich and poor, powerful and marginalized. It also recorded the widespread violence of the military uprising. One extraordinary scene captured a crewmember's own execution: the film's cameraman shot on film a soldier shooting him. Copies of the documentary's raw footage in Chile were destroyed along with all previously made Guzman films. Outside of the country, The Battle of Chile received much exposure, was screened at the Cannes Film Festival in 1975 and 1976, and was awarded prestigious prizes. It became a mainstay of exile solidarity meetings.

Information on torture, execution, and imprisonment was transmitted to the international community through exile efforts. One such instance was the 1977 Canadian Enquiry into Human Rights in Chile that linked exiles with human rights groups in Chile. Evidence of the dictatorship's human rights violations was documented by means of testimony before Canadian lawyers and representatives of faith groups and human rights organizations. The distance between "inside" and "outside" collapsed through the shared experience revealed in the personal testimony of the junta's victims. Survivors in exile, along with those direct from Chile, related experiences of torture, rape, and persecution. The conference marked the first time members of the Association of Relatives of the Disappeared had left Chile and were able to bear witness about their experiences in an international forum. The evidence elicited by the Enquiry was reported to the United Nations Human Rights Commission and formed part of the proceedings' record.

Additional campaigns were undertaken to gather international support for the cause, and especially to influence the United Nations' annual vote on the human rights conditions in Chile. ${ }^{26}$ International conferences were organized to expose the human rights crimes of the military dictatorship, many held in Europe, some under the auspices of the World Peace Council. A key component of these efforts was the introduction of testimonial evidence in order to substantiate charges against the military junta. In the aftermath of the coup d'état, the International Commission of Enquiry into the Crimes of the Military Junta was established in Helsinki. With the full participation of exiled
Popular Unity leaders, the Commission conducted factfinding missions to collect testimonial evidence of the violation of human rights in Chile. The Commission formed a Juridical Sub-Commission in order to collect and assess the information that was then published in documents widely distributed to international bodies. The Document of the Meeting of the International Commission of Enquiry into the Crimes of the Military Junta in Chile held in Berlin, GDR, February 6, 1977, reveals that it was attended by exile leaders of Popular Unity, including Sergio Insunza, minister of justice under Allende and by “. . . lawyers of differing political views from Great Britain, France, Spain, the USSR, Austria, the Federal Republic of Germany, Finland, and the GDR."27

Contributions to the body of evidence were made at national levels through exile organizations. In Canada, Chilean associations put out the monthly bulletin, Venceremos, published in English, French and Spanish during the 1970s. The newsletter contained articles on secret detention centres, testimony from the regime's victims, and news of the internal resistance and external solidarity efforts. The Canadian Council of Churches assisted by publishing A Testimony from Chile following the coup d'etat. The Council presented "... this document as an authentic testimony by one man of the events that have transpired. We know this man and the sources that he has used for his information ... "28 The document is divided into sections entitled "Outrages Committed against Human Rights," "Human Rights, A Matter of Freedom," and "Perspectives for the Future." Chile Ontario Information Centre's newsletters proclaimed that the group ". . . feels obliged to explain to Canadians what actually changed . . . with regard to the Junta's maneuvers." 29

A primary function of these events was to challenge the dictatorship's newly devised tactic of making people disappear inside Chile with testimonial evidence. Names, faces, and biographies of the disappeared ones were publicized by the exiles. Amnesty International in 1977 established a major campaign on behalf of disappeared Chileans incorporating information produced by exiles.

1977's Canadian Enquiry into Human Rights also marked the first time that one of the exiled cultural ambassadors of the Popular Unity government performed in Canada. The musical group Quilapayun ended the conference with an a cappella rendition of "El Pueblo Unido" and this was followed by a concert held in the University of Toronto's Convocation Hall. An audiocassette of the concert produced by the Toronto Chilean Association memorialized the event. Members of the group opened the concert with a piece describing the struggle during these "four long years of exile." The concert was a carefully orchestrated compilation of songs designed to uplift and to 
remember. It opened with "Te Recuerdo Amanda" ("I Remember You Amanda"), one of Victor Jara's most famous compositions, and ended with "El Pueblo Unido," characterized by the group as "the most important song in our actual repertoire."

This concert became for Canada the first of many tours by Popular Unity celebrities Quilapayun, Inti Illimani, and Angel and Isabel Parra. The concerts succeeded in heartening the spirits of the exiled communities as well as furthering support for their cause by engaging members of the host society. Cultural events took on profound meaning for the exiles as they served to provoke memory and preserve a spirit of resistance. For the exiled musicians, the concerts provided a means to preserve the cultural heritage of the New Song Movement censored by the junta. In addition, by publicly playing the internally banned Andean instruments, exiled artists engaged in acts of resistance.

Many of the exiled artists had been caught outside of Chile when the coup took place, after which they were refused re-entry into the country. They had been part of an eleventh-hour effort by Popular Unity to generate international support for its beleaguered government. These musical groups had been active participants in la nueva cancion chilena, the Chilean New Song Movement, which sought to meld music with an anti-colonial/imperialist political consciousness in support of national sovereignty. The movement aimed to develop indigenous roots and establish a popular audience. It was characterized by the use of aboriginal names and traditional Andean instruments such as the charango, zampona, and quena. ${ }^{30}$

In exile, the musical groups created their own means of protest to the military regime. Quilapayun teamed with Joan Jara, British-born widow of the group's first musical director, the executed Victor Jara, on a worldwide tribute tour. In Montreal, the group staged their operetta, La Cantata de Santa Maria de Iquique, with the participation of Quebec chanteuse Pauline Julienne. Based on the 1908 massacre of striking miners and their families in the country's northern mining district, Quilapayun retold the story of the historic event in light of contemporary Chilean resistance. The group reworked their popular pre-coup songs such as "La Batea"("The Washbasin") with new lyrics denigrating the military dictatorship. The rousing choruses of "Malembe" invited audience members to join in casting an evil spell on junta members.

Inti Illimani presented an international tour, "Chile in Our Hearts," with a view to protest forced exile. At this time, the group began to develop and broaden its repertoire to reflect the culture of Italy, their country of asylum. ${ }^{31}$ Horacio Salinas, a founding member of Inti Illimani, ex- plained the problem of remaining in suspended animation waiting for the day of return. ${ }^{32}$

Exile produces two types of problems for artists. It causes a strong uprooting for artists and certain incomprehension by the new audience. Artists have a key or a code that was difficult for some countries to understand, so some artists stopped producing. The other problem is that for many the reason to create art was rooted in the land, the country and the history where they had been producing. So there were some people that continued to play the same music. But in another country with another history and also in a new epoch, there was a terrific shift which left many of those involved in this music removed from artistic reality. ${ }^{33}$

Salinas posed the nuanced dilemma faced by exiles: to "keep the flags of struggle very high" or "to open our ears a little and the windows of our house to understand what was happening in what was our second house ....We lived many years-from 1973 to 1978 - perplexed, without putting curtains on the windows, with our bags packed always ready to return." 34

When the Pinochet regime promulgated its own constitution in 1980, exiles came to understand that their predicament would be a long-term one. The military dictatorship that had been expected to fall had, instead, managed to institutionalize its claim to political leadership. Simultaneously, human rights and grassroots organizations were rebuilding inside the country. Even before this, exile activity had begun to modify its focus to showcase and support resistance activity in Chile. In 1978 and 1979, exiles sponsored concert tours of opposition musical groups recently formed inside the country. These included Ortiga and Illapu, both associated with Agrupacion Cultural de Universidad (ACU, or the University Cultural Association). ${ }^{35}$ Exiles engaged in sympathy hunger strikes in 1977 and 1978 to support those undertaken inside Chile by the Association of Relatives of the Disappeared in efforts to obtain information on the fates of their family members.

During this time, inside Chile, the opposition began to incorporate the right of Chileans to live in their country into the roster of human rights demands. A Committee for the Right to Return was organized and employed the metaphor of a bell jar, depicting Chilean exiles under glass to illustrate their plight. In 1978, the ACU presented a photographic exhibition of artists in exile that openly proclaimed the names, faces, and activity of the banished ones. Efforts to dislodge the geographical separation of opposition Chileans continued to be mounted from inside and outside of the country.

Exiles also were able to provide a measure of security for internal opposition by facilitating the participation of for- 
eign observers to Chilean activity. Canadian Geneva Parker attended the first two congresses of the Women's Department of the Coordinadora National Syndicato (National Workers Coordination) in 1978 and $1979 .{ }^{36}$ Lake Sagaris and Lorraine Mitchell represented Canada's National Union of Students at the ACU's founding conferences in 1980 and 1981. Foreign delegates were able to bring out of Chile eyewitness testimony, material, and information that was duplicated and widely distributed. By these means, exiles were able to render assistance to the newly launched opposition groups and to continue to expose the repressive practices of the military regime.

By 1983, the fulcrum of resistance to the dictatorship had shifted to Chile. With the inception of the national days of protest inside the country, the exile community organized to support this activity. The "circles of silence" created by the culture of fear had been punctured in Chile as hundreds of thousands of Chileans publicly displayed their opposition to the dictatorship by mean of monthly demonstrations and work stoppages. The massive numbers who openly protested the regime fueled hopes among exiles that they would soon be able to return.

By this time, some exiles had been able to return to Chile while others on the Lista Nacional continued to be barred from the country. And still others continued to be expelled by the regime. For example, in August 1981, four opposition leaders of centre-left political parties were exiled because the regime proclaimed them to have "a defiant attitude that the government will not tolerate." 37

Some exiles went back to Chile clandestinely and joined the resistance. Others surreptitiously entered the country to gather documentary evidence. Nobel-Prize-winning Colombian author Gabriel Garcia Marquez chronicled the exploits of exiled filmmaker Miguel Littin, when he secretly entered the country in 1985 in order to make a documentary of life under the Pinochet regime. ${ }^{38}$ Littin had disguised himself as an Uruguayan businessman and, through subterfuge, shot one hundred thousand feet of film in six weeks. The two-hour film Acta General de Chile (General Document on Chile) comprised footage of a myriad of views of the country, including the interior of Pinochet's office. Screened at film festivals (a four-hour version was televised in Cuba), it was said to ". . . gently register the exile's nostalgia and surprises." 39

Acta General de Chile served as an indication of the constricted vision of long-term exile. The film was critiqued by some for idealizing Allende's Chile and thus it “. . . muddles his memory". The film was deemed to be history "... as hagiography." 40 The tenderly photographed images of Chile evoked the exile's imagined memories of land, sea, desert, and mountains and exposed a predicament of long- term exile. Writing about the work of Chilean-Canadian photographer Rafael Goldchain, Alberto Manguel described the dilemma of exile:

Within a country, inside a space, the eye sees its surroundings and reaffirms them. From outside—seen as memory, dream, longing invention-the exile sees the country as it never is ... The exile's task is twofold: to procure himself as image of the absent country that will allow him a constant point of reference, and to procure for others an image of that same country that will not lend itself to easy cliches and mere local colour. ${ }^{41}$

Nostalgia is a permanent condition of exile. The term itself is derived from the Greek "nostos-return home, and algia-longing." ${ }^{42}$ Forced exile can be described as a punishment without end. The sentence is one that is lived out daily and is only intensified when return is made possible. Boym depicts this fate as "... the luxury (or curse) of being able to criss-cross the border." 43

Read through a lens of pain and dislocation, the state of exile continues to embody a punishment that never ceases; it is only transmuted as time goes on. Exile transcends the generations of its victims, affecting families permanently as children and grandchildren experience anew the loss of family and culture and the pain of their elders.

Mindful of Said's caution that exile can never be romanticized, Chilean exiles nevertheless managed to construct an embodied site of struggle. ${ }^{44}$ Through their resistance, solidarity strategies, and commemorative practices, Chileans created and inhabited a newly devised distinct space. From this vantage point, they filtered information coming from "inside" and amplified and disseminated vestiges of the past. With their emphasis on solidarity practices, they were able to create an expanse both to contain memory and to produce opposition to the military dictatorship. It was into this constructed site of struggle that General Pinochet inadvertently fell when he was arrested in London in October $1998 .{ }^{45}$

When Chile's transition to democracy was commemorated with the Acto de Democracia on March 12, 1990, President Patricio Aylwin entered the National Stadium on foot to the strains of Verdi's Nabucco, symbolizing a return from exile. The anthem had originally been written as a celebration of the Jewish people's return from Babylonian captivity. While Aylwin had not been in exile, the choice of music symbolized the restoration of democracy and a healing of Chile's body politic. One component of the democratic transition's tasks was the creation of the National Office for the Return on July 31, 1991. While the office was fraught with problems, it was instituted to assist exiles with costs of returning and re-establishing livelihoods. 
For those exiles who chose to return to Chile, a new process of renegotiating identity began. They found themselves to be in a different country than that they had left or remembered, one that had been profoundly altered by seventeen years of military dictatorship. Dr. Raul Berdichevsky described the impact of finding his Chilean reality altered when he returned from Canada:

That which made me feel very Chilean-the values and basic principles of life-had vanished. That society no longer existed. It cast into sharp relief the fact that I too had been altered by life in exile. Clearly, exile contains man elements of movement and is not just the eternal rumination of the past. ${ }^{46}$

Within the Chilean diaspora, children and grandchildren of exiles began to produce representations of their own cultural memory. Films, songs, plays, and poems were created from the stance of second and third generations of Chileans. One young artist poetically captured the spirit of a transnational identity:

\author{
Two continent reside on the planes of my \\ horizons. \\ I am all the people who have died. I am all the \\ people who have left. \\ I am... \\ I was a small seed. Now I am two hearts, two \\ shorelines, two maps. \\ Demarcation and boundaries led me to this. \\ A border within myself has been erased. \\ Replaced by so much sound, beauty, and \\ life. \\ Gracias a la vida... ${ }^{47}$
}

In May 2001, Canada's Governor General, Adrienne Clarkson, led a delegation to the Southern Cone in order to establish closer hemispheric ties. In Chile, she said "Chilean poets, writers, academics and students have rejuvenated Canadian society, at the same time that it was enveloping them with safety." ${ }^{48}$ During this visit, Clarkson signed an agreement with the National Library of Chile to repatriate the fruits of Chilean-Canadian exile achievement. The Periodical Writers Organization of Canada administers "Project Adrienne" with the objective of repatriating Chilean exile cultural products.

Memory nurtured in exile enabled the symbols and principles of the deposed Popular Unity movement to be conserved and commemorated, in direct opposition to the dictatorship's design. Resistance strategies facilitated the remembrance of people and political philosophy and preserved elements of material culture that were in danger of obliteration. Through the measures taken by exiled survi- vors, evidence was produced and maintained that has the propensity for historical inquiry and the possibility of reinsertion into the Chilean national narrative. As the transition to democracy extended throughout the 1990s, a complex and delicate process of resistance memory, coming from both inside and outside of Chile, persisted in reintegrating itself into Chilean national life.

\section{Notes}

1. Ricardo Trumper and Patricia Tomic, "From a Cancerous Body to a Reconciled Family: Legitimizing Neoliberalism in Chile," in Household, Gender and Culture: International Perspectives, ed. Susan Ilcan and Lynne Phillips (South Hadley, MA: Bergin and Garvin, 1998) 3-18.

2. Ariel Dorfman, Heading South, Looking North: A Bilingual Journey (New York: Farrar, Straus and Giroux, 1998), 201.

3. In October 2000, human rights lawyer Fabiola Letelier filed suit on behalf of more than six hundred thousand exiled Chileans and more than nine thousand Chileans refused entry into their country by the military junta. Exile organizations claimed one million Chileans were in exile in the aftermath of the coup d'état.

4. For more on Canada's official reluctance to accept refugees from Chile see Gerald E. Dirks, Canada's Refugee Policy: Indifference or Opportunism? (Montreal: McGill-Queens University Press, 1977); Reg Whitaker, Double Standard: The Secret History of Canadian Immigration (Toronto: Lester and Orpen Dennys, 1987); and Joan Simalchik, "Part of the Awakening: Canadian Churches and Chilean Refugees" (master's thesis, OISE-University of Toronto, 1993).

5. Carmen Rodriguez, and a body to remember with (Vancouver: Arsenal Pulp Press, 1997), 19-20.

6. Monica Escobar, "Exile and National Identity: Chilean Women in Canada," (PhD dissertation, OISE-University of Toronto, 2000), 252.

7. Salvador Allende, "Last Word," in Salvador Allende Reader, ed. James D. Cockcroft, (Melbourne: Ocean Press, 2000), 240-241.

8. Judith Pilowsky and Carlos Torres, "El Exilio: un crimen impune," (conference paper, University of La Serena, November, 2000), 6 (my translation).

9. Escobar, ii.

10. Joseph Wittlin, quoted in Paul Tabori, The Anatomy of Exile: A Semantic and Historical Study (London: Harrap, 1972), 32.

11. The Garden of Exile is described as "Not your garden of paradise...It has a dizzying and confusing effect to it"; see $<$ http://www.geocities.com/snufflesyoung/bvo/BVOE.htm>.

12. E.H. Carr, The Romantic Exiles Middlesex, England: Penguin, 1933). Carr wrote about pre-Marxist revolutionary Europeans and asserted, "In them Romanticism found its last expression" with a remaining "handful of dare-devil terrorists in Russia and of picturesque anarchists in western Europe...” (321).

13. Edward Said, Reflections on Exile (Cambridge, MA: Harvard University Press, 2000), 174. Said points out that while Carr 
and "history romanticizes" the state of exile, it "cannot be made to serve notions of humanism."

14. For example, Canada signed the 1951 United Nations Convention in 1969, but only established refugee status in law in 1976. Previous refugee movements were admitted by special Cabinet decisions. It was in response to the Chilean situation, and the lobby of a coalition of Canadian civic organizations, that Canada set up its refugee determination system.

15. The "Diagnostic and Statistical Manual of Traumatic Stress" (DSM-IV-TR) lists "removal from home" under the housing category of psychosocial and environmental problems posing a potential risk factor for stress. Refugees are removed from both their homes and homelands. In the social environment category, acculturation problems are listed. Quick Reference to the Diagnostic Criteria. (Washington, DC: American Psychiatric Association, 2000), 43.

16. Ana Maria Barrenechea constructs a distinct category for "the fires of exile" in "Under Many Fires" in Canadian Women's Studies: An Introductory Reader, ed. Nuzhat Amin, et al. (Toronto: Inanna Publications, 1999), 227.

17. Ximena Fornazzari, "The Trauma of Exile and Resettlement," in Community Support for Survivors of Torture: A Manual, ed. Kathy Price (Toronto: Canadian Centre for Victims of Torture, 1995), 15.

18. Leon and Rebecca Grinberg state, "Exile converts the search for truth, a voluntary migration, into punishment and involuntary migration," and compare it to Adam and Eve's banishment from the Garden of Eden; see Psychoanalytical Perspectives on Migration and Exile (New Haven: Yale University Press, 1989), 8.

19. Ignacio Martin Baro, Writings for a Liberation Psychology, ed. A. Aron and S. Corne, (Cambridge, MA: Harvard University Press, 1994), 188. Martin Baro here writes concerning the effects of the "Social Lie" on populations living under conditions of war or dictatorship. This notion may be extended to exile populations who do not have opportunity to have their living reality validated by the larger society or "reflected" back to them with any accuracy or understanding.

20. Alberto Manguel, "Introduction," in Nostalgia for an Unknown Land, by Rafael Goldchain (Toronto: Lumiere Press, 1989).

21. For example, Canada recognized the junta eighteen days after the September 11 coup d'état.

22. However, Chileans often discovered elements of "typical culture" in exile. Many professed that they learned to dance the cueca and to prepare national dishes in countries of exile.

23. Rodriguez, 89.

24. Allende.

25. Guzman had intended to make a documentary depicting the life of Popular Unity government. Instead, because of the timing of the coup d'etat, he filmed its demise.

26. Chile was condemned by the United Nations General Assembly for human rights violations each year during the dictatorship despite lobby efforts to normalize its image.
27. "Documents from the Meeting of the Juridical Sub-Commission....," Berlin, 1977, Toronto Action for Chile archives.

28. Anonymous, A Testimony from Chile (Toronto: Canadian Council of Churches, n.d.), Toronto Action for Chile archives.

29. Chile Ontario Information Centre, May 12, 1978, Toronto Action for Chile archives.

30. Angel and Angel Parra were children of folklorist Violetta Parra, founder of the New Song Movement. Both groups, Quilapayun ("Five Bearded Men") and Inti Illimani ("Messengers of the Gods"), who performed in traditional ponchos, had worked with Victor Jara. All were active supporters of Popular Unity.

31. Quilapayun, exiled in Paris, composed a musical thank you for solidarity shown by the French people. The piece, "Waltz of Colombe," used the Andean flutes, quenas and zamponas, to recreate the sounds of the traditional French calliope.

32. At a 1981 Toronto concert by Inti Illimani, Horacio Duran, another founding member, told the audience that Chileans had taken the world record for having the shortest index fingers from the Spanish people. This condition, he explained, comes from pounding the table with the finger emphasizing that "this year we go home." When they did return to Chile in 1989 after an eighteen-year exile, the group declared that it had been on the longest tour in history.

33. "A Conversation with Horatio Salinas of Inti Illimani," Center for Latin American Studies, University of California, Berkeley, October 6, 1999, 4, <http://ist-socrates.berkeley.edu:7001/ Events/intiillimani-index.html $>$.

34. Ibid., 4-5.

35. After one such tour, Illapu was refused re-entry into Chile and thus joined the ranks of exiled artists. Their song "Vuelvo," written to demonstrate their determination to return, became an anthem for Chileans in exile.

36. The CNS was the labour federation that grew in the vacuum left by the banning of CUT (Central Unica de Trabajadores, or Workers' Central Union of Chile).

37. Derechos Chile website, Chronology.

38. Gabriel Garcia Marquez, Clandestine in Chile: The Adventures of Miguel Littin (New York: Henry Holt and Co., 1986.) Littin had been appointed head of the Chilean film industry by Allende in 1970.

39. Michael Wood, New York Times Book Review, August 9, 1987. 40. Ibid.

41. Alberto Manguel, "The Memory of Exile." (Toronto: Blackflash, Fall 1988).

42. Svetlana Boym, The Future of Nostalgia (New York: Basic Books, 2001), xiii. Boym maintains (p. xvi) that nostalgia “... is not just an individual sickness but a symptom of our age, a historical emotion."

43. Ibid., 331.

44. Edward Said.

45. Jack Straw, UK Minister of State who allowed the General's arrest by Scotland Yard, was an early member of the Chilean solidarity movement.

46. Dr. Raul Berdichevsky, interview, August 13, 2001, Toronto). 
47. Marilo Nunez, "North Meets South," Canadian Woman Studies 19, no. 3: 95.

48. Paul Knox, "Military Rule Drew Canada, Chile Closer", Globe and Mail, May 9, 2001, A12.

Joan Simalchik, Ph.D., lectures and coordinates the Study of Women and Gender Program at the University of Toronto at Mississauga. Dr. Simalchik served as the founding executive director of the Canadian Centre for Victims of Torture and her dissertation, "If Memory Serves: Constructing the Democratic Project in Chile, "was informed by her solidarity activity with the Chilean community in Canada.

(C) Joan Simalchik, 2006. This open-access work is licensed under a Creative Commons Attribution-NonCommercial 4.0 International License, which permits use, reproduction and distribution in any medium for non-commercial purposes, provided the original author(s) are credited and the original publication in Refuge: Canada's Journal on Refugees is cited. 